\title{
SPIRIT NILAI GOTONG ROYONG DALAM BANJAR DAN BESIRU PADA MASYARAKAT SASAK-LOMBOK
}

\author{
${ }^{1}$ Lalu Murdi \\ ${ }^{1}$ Universitas Hamzanwadi \\ Murdilalu2014@gmail.com
}

\begin{abstract}
ABSTRAK
Masyarakat Sasak-Lombok dengan segala keunikan budayanya memiliki nilai-nilai tersendiri baik yang berkembang dalam ranah internal maupun merupakan hasil akulturasi dari etnis lain. Beberapa nilai goyongroyong yang berkembang pada masyarakat Sasak seperti banjar dan besiru juga dikenal pada masyarakat Bali namun memiliki warna dan ciri khas sesuai dengan masyarakat Sasak-Lombok. Hasil penelitian menunjukkan bahwa banjar dan besiru baik pada masa lalu maupun saat ini di pedesaan masih memberikan kontribusi yang positif dalam menciptakan nilai-nilai kebersamaan yang khas. Tentu saja dalam perkembangannya saat ini sudah banyak terjadi perubahan, salah satunya disebabkan oleh pandangan masyarakat yang dipengaruhi baik oleh perkembangan ekonomi, pekerjaan, sistem sosial, dan lain sebagainya, namun hal ini penting untuk dimunculkan sebagai bagian dari khasanah budaya masyarakat yang baik untuk mendeskripsikan keunggulan mereka dalam menjalankan kerjasama baik pada masa lalunya maupun saat ini.
\end{abstract}

Kata Kunci: Spirit, Gotongroyong, Banjar, Besiru.

\section{PENDAHULUAN}

Keadaan geografis yang membagi wilayah Indonesia atas kurang lebih 3.000 pulau yang terserak di suatu daerah ekuator sepanjang kurang lebih 3.000 mil dari timur ke barat dan lebih dari 1.000 mil dari Utara ke Selatan, merupakan faktor yang sangat besar pengaruhnya terhadap terciptanya pluratitas suku bangsa di Indonesia (Nasikun, 2011: 43).

Bentangan kepualauan Indonesia tersebut telah menciptakan aneka warna suku bangsa dengan jumlah yang dapat diidentifikasi melalui perbedaan-perbedaan sesuai dengan pendekatan yang digunakan para ahli. Hilder Geertz, misalnya, menyebutkan adanya lebih dari 300 suku-bangsa di Indonesia, masing-masing dengan bahasa dan identitas kultural yang berbeda-beda. Adapun Skinner menyebutkan adanya lebih dari 35 suku-bangsa di Indonesia, masing-masing dengan bahasa dan adat yang tidak sama (Nasikun, 2011: 44). Bahkan lebih banyak lagi, Sri-Edi Swasono (2014), serta Andi Ima Kesuma (2012), mencatat tidak kurang dari 501 suku bangsa di Indonesia yang masingmasing memiliki kekhasan tersendiri (Swasono, 2014: 31-34). 
Banyaknya suku-bangsa itulah yang menyebabkan Indonesia dikenal sebagai bangsa yang multikultural atau negara dengan masyarakat majemuk. Masyarakat yang demikian ini secara horizontal dapat dibedakan berdasarkan beberapa hal, seperti etnik dan rasa tau asal usul; bahasa daerah; adat istiadat atau prilaku; agama; pakaian, makanan, dan budaya material lainnya (Hermianto \& Winarno, 2011: 100).

Satu diantara sekian banyak suku-bangsa di atas, suku Sasak merupakan bagian dari identitas Indonesia yang tidak kalah menariknya sebagai bagian dari bidik kajian tersendiri. Suku Sasak merupakan salah satu diantara beberapa suku yang ada di NTB selain Bayan, Bima, Dompu, Donggo, Kore, Mata, Mbojo dan Sumawa (Swasono, 2014: 42-44), memiliki ciri dan karakteristik tersendiri baik dalam pamahaman suprastruktur sosial, dan struktur sosil.

Terlepas dari adanya perbedaan pandangan di atas, khususnya dalam sistem sosial masyarakat Sasak mencakup banyak hal, mulai dari kebiasaan-kebiasaan masyarakat, integrasi sosial, stratifikasi sosial dan lain sebagainya. Dalam kaitannya dengan bentuk integrasi sosial yang dibangun dalam sistem sosial yang ada, masyarakat Sasak telah membentuk integrasi/solidaritas sosial yang memiliki nilai fungsional. Terkait dengan itu pada masyarakat Sasak ada bentuk tersendiri yang dapat mengikat rasa kolektivitas masyarakatnya. Salah satunya adalah adanya pembentukan kelompok banjar, sistim besiru, serta beberapa kegiatan kolektif lainnya seperti pada saat pembangunan rumah, membangun tempat umum (seperti Masjid, Mushalla, Madrasah, dan lain-lain), acara begawe, acara kematian dan lain sebagainya.

Bagian dari sistem sosial yang memiliki nilai fungsional di atas seperti besiru dengan proses penanaman nilai intergrasi yang kuat di dalamnya, terutama sekali dalam hal saling tolong-menolong pekerjaan di sawah yang merupakan bagian penting dari kehidupan masyarakat Sasak yang agraris, kemudian pembentukan sistem banjar yang sampai saat ini memiliki nilai gotong-royong tersendiri untuk meringankan beban sesama warga masyarakat Sasak yang keluarga atau anaknya menikah, dan banyak lagi sistem gotong royong lainnya, serta budaya simbol dari adanya persatuan masyarakat Sasak. Semua ini memberikan arti penting akan sistem persatuan sosial pada masyarakat Sasak sendiri. Namun disadari bersama bahwa, beberapa sistem integrasi yang dipaparkan dalam buku ini pada umumnya sudah banyak berubah, meskipun 
sebagian diantaranya seperti persatuan kelompok banjar masih dapat terus ada sebagai bagian dari kelanjutan integrasi yang sudah memudar tersebut.

Meskipun banjar dan besiru ini diyakini merupakan akulturasi dari etnis Bali, tetap saja substansinya sudah mengakar kuat pada masyarakat Sasak. Selama spirit kebersamaan ini fungsional untuk menguatkan rasa kebersamaan dan memperkuat nilainilai gotongroyong, selama itu juga hal ini penting untuk diungkap sebagai bagian dari khazanah masyarakat dalam realitas objektif.

Memasuki abad ke-21 ini tentunya integrasi yang kuat pada masyarakat Sasak di Lombok lebih luasnya dapat dilihat pada masyarakat agraris yang tinggal di pedesaan. Masyarakat pedesaan dalam hal ini bisa diartikan dalam tanda kutip, bukan masyarakat yang terbelakang dalam pendidikan dan ekonomi, namun mereka tinggal pada lingkungan masyarakat peguyuban dengan ciri-ciri masyarakat desa yang masih melekat di dalamnya. Hanya saja kecendrungan konflik yang terjadi lebih banyak diakibatkan oleh adanya pertarungan politik. Secara teoretis (Setiadi \& Kolip, 2011), hal inilah yang biasanya menyebabkan adanya disharmonis masyarakat dengan ciri masyarakat pedesaan yang agraris tersebut.

Perkembangan masyarakat Sasak dalam segala aspek, dan adanya kebutuhan yang semakin meningkat, sehingga pandangan ekonomi juga ikut berubah. Semua ini menyebabkan perubahan tersendiri pada beberapa sistem sosial yang pernah menjadi nilai dasar persatuan masyarakat Sasak yang kini sudah menipis untuk tidak mengatakan hilang sama sekali, dan beberapa sistem integrasi sosial yang masih kuat sampai saat ini.

Nilai kebersamaan yang dapat diidentifikasi dalam sistim besiru, seperti yang akan diuraikan selanjutnya menunjukkan perubahan tersendiri. Dimana nilai fungsional yang begitu kental sebelum tahun 1990-an, kini mulai terkikis, banyak faktor yang berkelindan di dalamnya. Perubahan sosial, ekonomi, dan lain sebagainya.

Jelas bahwa pada masyarakat Sasak, baik pada masa lalunya, maupun saat ini, memiliki nilai-nilai dan norma yang diaplikasikan dalam sistem sosial kemasyarakatan yang dapat meningkatkan solidaritas sosial antara sesama warga masyarakatnya baik dalam arti sempit maupun luas. Beberapa sistem integrasi sosial tersebut baik yang sudah tidak berlaku lagi, atau pun yang masih bertahan sampai saat ini perlu secara 
Spirit Nilai Gotong Royong.....- Lalu Murdi

bersama-sama dianalisa, dimunculkan, dan dikaji sebagai bentuk dari local wisdom masyarakat Sasak sebagai bentuk integrasi sosialnya secara menyeluruh.

\section{METODE PENELITIAN}

Pendekatan penelitian yang digunakan dalam penelitian ini adalah pendekatan kualitatif. Penelitian kualitatif berusaha memahami fact yang ada di balik kenyataan, yang dapat diamati atau diindra secara langsung. Dalam istilah metode ini, fakta yang berada yang berada di balik kenyataan langsung disebut verstehen (Maryaeni, 2005: 3). Sejalan dengan hal tersebut, verstehen sendiri seperti dijelaskan Kuntowijoyo (2008) dan Hardiman (2003), merupakan pengalaman "dalam" yang menembus jiwa dan seluruh pengalaman kemanusiaan. Demikian juga Max Weber (Kuswarno, 2009) menjelaskan versetehen mengarah pada suatu tindakan bermotif demi tujuan yang hendak dicapai, sebagai salah satu metode untuk memahami motif dan makna di balik tindakan manusia.

Adapun metode penelitian yang digunakan adalah metode etnografi. Dimana didalamnya lebih banyak mempelajari peristiwa kultural, yang menyajikan pandangan hidup subjek yang menjadi objek penelitian Studi etnografi merupakan salah satu deskripsi tentang cara mereka berpikir, hidup dan berperilaku, dan merupakan metode penelitian yang mempelajari bagaimana perilaku sosial dapat dideskripsikan sebagaimana adanya (Assifie, B, 2001: 152).

\section{HASIL PENELITIAN DAN PEMBAHASAN}

\section{A. Spirit Kebersamaan dalam Kegiatan Banjar}

\section{Konsep Kebersamaan dalam Banjar}

Menelisik pengertian banjar, dapat dirujuk pada beberapa pendapat diantaranya dalam kamus Kawi-Indonesia karangan Wojowasito mengertikan banjar sebagai “baris; lingkaran". Pengertian yang hampir sama dengan itu dalam kamus Jawa KunoIndonesia karya L. Mardiwarsito, mendifinisikan banjar dengan "deret; jajar, baris atau binanjar". Sementara itu dalam kamus Kawi-Jawa gubahan C. F. Winter Sr dan R. Ranggawarsita, kata banjar atau banjaran diartikan sebagai “urutan atau urut-urutan”. Sedangkan dalam Kamus Besar Bahasa Indonesia, kata banjar merujuk pada makna 
“jajar, deret, leret, baris", selain itu diartikan juga sebagai "bagian dari desa, setingkat rukun warga atau dukuh yang dikepalai seorang Keliang”. Adapun dalam terminologi masyarakat Lombok, banjar dapat dipahami sebagai "persekutuan komunitas kecil yang eksistensinya berada pada setiap gubug atau kampung" (Tolomundu \& Yamin, 2008: $13)$.

Terdapat beberapa istilah banjar yang terkenal pada masyarakat Sasak-Lombok. Beberapa istilah tersebut diuraikan oleh Sudirman dan Bahri (2014), sebagai berikut:

1. Krama Banjar, yaitu suatu (kelompok adat atau perkumpulan masyarakat adat yang anggotanya terdiri dari penduduk di suatu kampong/dusun (Sasak: dasan) atau berasal dari beberapa desa, yang anggotanya mempunyai tujuan yang sama. Tempat pertemuan para anggota banjar disebut bale banjar yaitu rumah tempat pertemuan berwujud balaerung atau berugaq sekepat, sekenem, atau sekewulu.

2. Krama Banjar Subak, adalah perkumpulan para petani (penggarap sawah pertanian) atau perkumpulan petani pengguna air sawah yang berada dalam wilayah subak tertentu.

3. Krama Banjar Merarik, yaitu banjar pemuda yang membentuk krama banjar untuk mengadakan arisan kawinan. Uang iuran anggota banjar diberikan untuk membantu anggota banjar yang menikah.

4. Krama Banjar Mate, yaitu perkumpulan yang mengumpulkan iuran anggota untuk membantu anggota yang dapat musibah kematian. Dapat berupa kain putih untuk kafan dan uang belasungkawa untuk membantu biaya kematian.

5. Krama Banjar Haji, yaitu sejenis perkumpulan haji, dengan pola sama seperti dana haji dari iuran anggota yang terkumpul, juga membantu anggota untuk bergotong royong dalam penyelenggaraan mulai dari persiapan sampai pulang dari Tanah Suci Mekah (Sudirman \& Bahri, 2014: 412-413).

Kegiatan banjar tersebut secara umum masih dominan pada dua kegiatan komunal masyarakat Sasak yaitu dalam acara pernikahan dan kematian. Disamping itu, semakin banyaknya masyarakat yang menunaikan ibadah haji, adanya krama banjar haji semakin dirasakan penting bagi masyarakat. Adanya revitalisasi banjar yang dilakukan beberapa gubug atau kampung di Lombok dengan modernisasi lembaga 
banjar, telah memberikan warna tersendiri dalam kegiatan banjar yang mampu menyesuaikan diri dengan kebutuhan masyarakat modern.

Semangat banjar sendiri berasal dari semangat besiru. Kata Besiru adalah bentuk aktif dari kata siru yang bermakna "ke-saling-an". Semangat besiru bersifat spontan, kolektif dan berlandaskan reme, yaitu sikap membantu atau menolong sesama dengan sukarela, senang hati dan ikhlas. Prinsip dasar yang menggerakkan besiru adalah keyakinan hidup memerlukan interaksi dan berbagi dengan sesama (Tolomundu \& Yamin, 2008: 14).

Besiru dengan demikian merupakan kata kunci dalam membentuk spirit kebersamaan pada masyarakat Sasak yang tidak hanya muncul dalam kegiatan banjar, sekaligus menjadi spirit kolektivitas lainnya. Apabila pada masyarakat suku Bugis di Sulawesi mengenal siri' sebagai kekuatan sentral dalam banyak aktivitas kehidupan, maka semangat besiru merupakan spirit kultural yang menggerakkan masyarakat Sasak di Lombok untuk menguatkan tali persaudaraan.

Secara umum baik pada banjar mate (mati) atau pun banjar merariq (pernikahan) bercirikan antara lain:

1. Berada hampir di setiap kampung atau gubug

2. Tidak mengenal manajemen pengelolaan tertulis

3. Katua dipilih secara musyawarah yang biasanya berdasarkan senioritas usia, atau karisma. Bahkan ada juga yang sekedar kesanggupan.

4. Kegiatan berjalan statis, hanya mengurusi prosesi kematian dan pesta perkawinan warga sebanjar.

5. Keanggotaan berdasarkan primordialitas-geneologis

6. Iuran anggota insedental dan spontan

7. Nyaris tanpa ada pertemuan berkala

8. Tidak memiliki bale banjar

9. Tidak memiliki program berorientasi ke depan

10. Cendrung menjadi organisasi warga yang konsumtif dan pasif. (Tolomundu \& Yamin, 2008: 14).

Dalam kelompok banjar posisi masyarakat relatif sama dan setara. Tidak ada patron dan tidak ada klien. Semua anggota banjar bergerak atas penggilan hati dan rasa 
simpati ketika memberikan dukungan kepada sesama warga (Tolomundu \& Yamin, 2008: 14).

\section{Modernisasi Melalui Revitalisasi Banjar}

Bagi Tolomundu \& Yamin (2007), revitalisasi banjar bisa dimaknai sebagai upaya kreatif, sistematis dan berkelanjutan untuk memperkuat modal sosial yang ada di dalam banjar. Memperkuat disini bisa bermakna memberi roh atau spirit baru. Bisa pula berarti mengembangkan roh atau spirit yang sudah ada. Sederhadanya, gagasan revitaslisasi banjar bertujuan menjadikan spirit besiru yang melahirkan energi sosial yang besar dan spontan di banjar, bisa terkelola untuk hal-hal yang produktif.

Paling tidak terdapat tiga pemikiran dasar yang cukup strategis untuk mempercepat pembangunan (demokratisasi) masyarakat desa di Lombok melalui revitalisasi banjar, yaitu:

Pertama, institusi lokal seperti banjar ada di hampir semua komunitas pedesaan di tanah air. Sekalipun tentu saja nama dan konteks sosial-kultural yang melingkupinya tidaklah sama. Tetapi institusi lokal itu sama-sama merupakan modal sosial yang tumbuh dan berakar di tengah masyarakat lokal.

Kedua, gagasan revitalisasi banjar adalah bentuk konkrit daro penerapan otonomi di tingkat lokal (dusun). Jika otonomi kita maknai sebagai upaya mendorong partisipasi sadar dan kritis warga dalam mendorong perubahan diri dan lingkungannya, maka gagasan revitalisasi institusi lokal seperti banjar adalah jawabannya.

Ketiga, ide revitalisasi banjar membuktikan sejatinya masyarakat lokal di pedesaan masih punya harapan besar untuk mendorong perubahan secara mandiri memang pengalaman di Lombok mengajarkan bukan barang yang mudah merevitalisasi institusi lokal yang sudah teramat lama terpasung dalam "penjara" pembangunan yang serba sentralistik. Tetapi dengan strategi yang tepat dan pelibatan penuh komunitas warga di banjar sebagai lokomotif perubahan, apa yang tidak mudahtadi, perlahan tapi pasti bisa membuahkan sesuatu yang menggembirakan. (Tolomundu \& Yamin, 2008: 17-18).

Revitalisasi banjar yang produktif tersebut lebih lanjut menurut Tolomundu dan Yamin (2007) dapat dilakukan salah satunya dengan moderinasi kelembagaan. 
Modernisasi kelembagaan tersebut diperkirakan akan melahirkan banjar dengan ciri baru, antara lain:

1. Memiliki bale banjar sebagai ruang budaya

2. Menerapkan manajemen pengelolaan yang demokratis, partisipatif, akuntabel dan berpijak pada nilai-nilai musyawarah dan silaturrahim.

3. Kepengurusan terstruktur berdasarkan kebutuhan dan dipilih secara demokratis.

4. Program dirancang dan berorientasi ke depan dengan menekankan nilai-nilai kreatif, inovatif dan produktif.

5. Keanggotaan terbuka bagi setiap warga selingkungan.

6. Adanya iuran anggota secara berkala.

7. Memiliki seperangkat kearifan lokal yang menjadi pegangan. Berbentuk institusi lokal yang dilembagakan.

Dalam konteks ini, bale banjar memiliki peran sentral sebagai ruang budaya. Hal ini sama dengan lembaga modern dengan adanya sekretariat bersama, hanya saja di bale banjar dapat juga dijadikan tempat pengembangan budaya lainnya, atau pun penyelenggaraan semacam pestival budaya, serta sebagai ruang pranata budaya.

Pengalaman dari beberapa gubuq atau dusun yang sudah melakukan revitalisasi kelembagaan banjar mendapatkan banyak manfaat, salah satunya dapat menjadi ruang budaya untuk melahirkan awik-awik yang mengatur banyak hal dalam struktur sosial masyarakat.

Disamping itu, dalam konteks pendidikan gender, bale banjar dengan spiritnya yang demokratis, menjadi ruang yang kondusif dalam menumbuhkembangkan potensi dan apresiasi kaum perempuan desa. Hal ini dapat menjadi antitesa dari adanya kecendrungan seperti yang dijelaskan Kesuma dan Lalu Murdi (2015) terjadinya deskriminasi, subordinasi, dan lain sebagainya pada kaum perempuan dalam sektor lainnya seperti dalam bidang pendidikan, pembagian hak waris, serta dalam sistem pernikahan pada masyarakat tradisional suku Sasak di Lombok. Berbeda dengan struktur sosial tradisional tersebut, dalam revitalisasi banjar, di bale banjar perempuan berinteraksi setara dengan laki-laki. Dimana, gagasan, pikiran, dan problematika mereka juga mendapat ruang yang sama untuk diperbincangkan dan dicarikan jalan keluar 
Spirit Nilai Gotong Royong.....- Lalu Murdi

(Tolomundu \& Yamin, 2008: 25).

\section{B. Spirit Gotongroyong dalam Besiru}

\section{Konsep Besiru}

Besiru merupakan bagian dari masa lalu masyarakat Sasak, meskipun keberadaannya yang dominan masih dirasakan beberapa puluh tahun sebelumnya dan sebagian kecil saat ini. Akan tetapi melihat perkembangan masyarakat akan pola kerja saat ini, dengan sendirinya jelas sangat sulit untuk dapat berlaku lagi pada masyarakat Sasak mendatang. Karena itu, generasi muda kita perlu mendapatkan dan memahami warisan masa lalu dari masyarakatnya yang sangat baik ini.

Pelestarian besiru sebagai bagian dari masa lalu masyarakat Sasak ini, dalam istilahnya Kuntowijoyo (2005), dapat "menjadi pendidikan moral” bagi generasi muda saat ini dan masa yang akan datang. Sejalan dengan hal tersebut, konsep Sam Wineburg (2006), mengajarkan masa lalu (dalam hal ini mengenai sistim besiru), tidak lain untuk dapat memetakan masa depan yang lebih baik. Pemetaan yang lebih baik untuk terus meningkatkan rasa kebersamaan dalam pergulataan kehidupan individual yang semakin bersemayam dalam kehidupan masyarakat.

Berdasarkan hal tersebut, maka perlu kiranya dianalisa dan diidentifikasi beberapa dampak positif yang dapat dirasakan dari adanya sistim begae besiru ini. Dengan demikian masyarakat kita, khususnya generasi muda dapat menjadikannya sebagai pelajaran yang berharga dan dapat menjadi salah satu basis dari kesadaran sosial mereka. Beberapa dampak positif dari adanya sistim besiru tersebut paling tidak dapat diuraikan berdasarkan dampak positif secara langsung dan tidak langsung:

Dampak positif begae besiru secara langsung pada masyarakat Sasak, setidaknya dapat diidentifikasi beberapa diantaranya adalah sebagai berikut:

1. Menguatkan solidaritas sosial masyarakat

Kebersamaan yang sering terjalin, yang salah satunya dengan sistem begae besiru, secara psikologis menyebabkan terjadinya ikatan sosial yang lebih kuat antara sesama. Bagaimana tidak, sambil bekerja, mereka dapat tertawa, bercerita, dan lain sebagainya yang mungkin tidak dapat dilakukan setelah mereka secara bersama-sama pulang bekerja. 
Dengan adanya sistim besiru ini sekaligus juga memiliki nilai lebih, diantaranya rasa persaudaraan diantara mereka semakin kuat, karena itu sikap saling tolong menolong pada pekerjaan lainnya, sikap seolah-olah sama-sama saling memiliki, dan sikap berat sama dipikul, ringan sama dijinjing secara tidak langsung dapat tumbuh dari adanya sistim besiru ini.

2. Meningkatkan hubungan kekeluargaan

Selain sama-sama saling mengenal antara satu dengan lainnya secara intens dan dalam waktu yang lama, penduduk pada suatu kampung atau dusun di Lombok dahulunya, dan sampai saat ini di daerah pedesaan, mereka juga pada umumnya memiliki hubungan kekerabatan. Sehingga bisa dikatakan dalam satu kampung biasanya merupakan gambaran dari keluarga luas yang pada umumnya memiliki hubungan kekeluargaan baik itu jauh maupun sebagai keluarga dekat.

Adanya hubungan kekeluargaan tersebut, dengan adanya sistim besiru ini tentunya secara tidak langsung akan dapat menguatkan hubungan persaudaraan yang ada. Hal ini tentunya akan berbeda dengan hubungan kekeluargaan saat ini yang lebih bersifat berkala dan tidak terlalu intens meskipun memiliki hubungan kekerabatan. Dahulunya, jika mereka memiliki hubungan kekerabatan, meskipun agak jauh, saling memperhatikan, membantu, bahkan secara khusus dalam waktuwaktu tertentu saling mengunjungi walaupun bukan pada momen-momen tertentu seperti yang lumrah kita kenal belakangan ini.

3. Terpelihara dan semakin menguatkan norma bersama.

Adanya pembagian kerja yang homogen, dimana setiap individu akan selalu berinteraksi bersama, serta memiliki kebutuhan yang tidak jauh berbeda, sekaligus didorong dengan adanya nilai solidaritas dalam bentuk sistim besiru tersebut, menyebabkan pelaksanaan norma-norma sosial akan berjalan dengan baik pada masyarakat Sasak dahulunya. Norma-norma tersebut bisa berupa sopan-santun dalam pergaulan hidup sehari-hari baik antara orang tua dengan sesamanya, orang tua dengan remaja, anak dengan orang tuanya, serta norma-norma sosial lainnya yang dianggap ideal oleh masyarakat Sasak dahulu biasanya berjalan dengan baik. Semua ini tidak lepas dari adanya sistem solidaritas sosial yang mengikat mereka, salah satunya adalah adanya sistim besiru ini. 


\section{Memudarnya Spirit besiru Dewasa Ini}

Sebagai bagian dari sistem sosial, besiru pada masa lalu Masyarakat Sasak menjadi bagian dari cerita orang tua saat ini yang masih menyaksikan kehidupan masyarakat yang sudah mulai individualis, meskipun dalam beberapa hal masih terkontrol oleh sistem budaya yang ada pada masyarakat.

Tidak jauh berbeda dengan sistem budaya yang berkembang pada masyarakat lainnya, besiru untuk saat ini sudah memudar bahkan tidak lagi dikenal oleh generasi muda Sasak sebagai salah satu bentuk sistem integrasi sosial yang pernah ada pada masyarakatnya. Tentunya disadari bahwa karena besiru ini bukan bagian dari sistem budaya, maka perubahannya pun lebih cepat terjadi jika paradigma sosial dan ekonomi dari suatu masyarakat berubah. Oleh sebab itu, secara teoretis, menghilangnya sistim besiru pada masyarakat Sasak lebih disebabkan adanya perubahan nilai orientasi dari masyarakat itu sendiri.

Memudarnya sistim besiru pada masyarakat Sasak secara umum, disebabkan oleh banyak hal seperti kurangnya kesempatan untuk saling membalas atau bales siru, adanya sistem upah dan lain sebagainya. Beberapa hal di bawah ini, paling tidak menyebabkan melemahnya sistim besiru pada masyarakat Sasak:

1. Berkembangnya Sistem Upah

Berkembangnya sistem upah pada masyarakat Sasak secara umum, menyebabkan sistim besiru ikut tergeser. Adanya upah langsung yang diberikan oleh pemiliki sawah merupakan motivasi tersendiri untuk bekerja. Hal ini tentunya tidak sama dengan sistim besiru yang akan dibalas dengan tenaga.

Artinya bahwa kebutuhan masyarakat saat ini yang instan dan berorientasi uang menyebabkan mereka lebih memilih untuk mengambil upah daripada mempertahankan sistim besiru yang sudah ada.

2. Kurangnya Kesempatan untuk Bales Siru

Berkembangnya sistem upah dengan menggunakan uang di atas, orang-orang juga secara individu akan bekerja pada siapa pun untuk mendapatkan uang. Pada musim-musim tertentu, seperti musim tembakau misalnya, jauh hari sebelum daun tembakau akan dipetik, pemiliknya sudah memberikan uang dan menyebarkannya pada siapa saja yang siap untuk bekerja di sawahnya. 
Karena itu, sepertinya sudah tidak banyak waktu lagi bagi masyarakat kita dewasa ini untuk sama-sama saling membantu pekerjaan sawah dengan cara besiru tersebut. Sistim upah dengan berbagai faktor yang saling berhubungan didalamnya menyebabkan kurangnya kesempatan untuk saling membalas siru.

3. Kebutuhan Masyarakat yang Semakin Banyak

Selain kebutuhan masyarakat yang semakin banyak untuk mencukupi kehidupan sehari-hari yang harus dibeli dengan menggunakan uang, maka proeoritas utama bekerja adalah untuk mendapatkan uang sebagai salah satu cara memenuhi kebutuhan hidup yang semakin hari semakin mahal, dan tentunya masyarakat kita, termasuk dalam hal ini masyarakat Sasak, adanya budaya konsumtif pada sebagian orang tidak terhindarkan.

Apa yang terjadi di era ini tentunya tidak sama dengan apa yang dihadapi oleh generasi 1950-an, dimana kebutuhan masyarakat masih sangat sederhana, dan sekarang ditandai dengan adanya kebutuhan yang tentunya menarik minat dan menyebabkan kebutuhan tersebut meningkat. Inilah salah satu faktor juga yang menyebabkan memudarnya budaya besiru ini.

\section{Semakin Terbukanya Lapangan Pekerjaan Lainnya}

Cerita orang tua sebelum kemerdekaan, atau setelah Indonesia Merdeka bahkan sampai tahun 1990-an mengenai lapangan pekerjaan tentu jauh berbeda dengan dengan kondisi saat ini yang dicirikan dengan semakin terbuka dan terspesialisasinya lapangan pekerjaan pada masyarakat Sasak.

Jika beberapa puluh tahun sebelumnya, katakanlah tahun 1960-an, apalagi setelah berkuasanya orde baru alat produksi pertanian modern (yang sesuai dengan masa itu) baru secara luas dikenal oleh masyarakat Sasak, apa lagi jenis pekerjaan lainnya tentu masih sangat terbatas, inilah yang menyebabkan fokusnya masyarakat untuk bekerja dalam bidang pertanian, dan salah satu cara untuk mempermudah adalah dengan sistim besiru.

Terbukanya lapangan pekerjaan lain, meskipun pada dasarnya mereka adalah petani, yang diterapkan tentunya adalah sistem upah. Masyarakat yang memiliki penghasilan ganda selain dari bertani kemungkinan besar akan menghabiskan waktu untuk bekerja di sektor yang secara langsung dapat memberikannya uang langsung, 
hasil pekerjaannya selain untuk memenuhi kebutuhan sehari-hari, sekaligus juga digunakan untuk pembiayaan sawahnya.

Kondisi di atas, meminjam istilahnya Harbert Spencer (dalam Soekanto, 1984: 66), pada masyarakat Sasak telah terjadi perubahan dari sistem pekerjaan yang homogen menjadi pekerjaan yang terspesialisasi dan heterogen. Karena itu, secara tidak langsung, sistim besiru sepertinya kurang dapat berlaku atau pun bertahan lagi pada masyarakat dengan ciri yang heterogen tersebut.

5. Tidak adanya nilai ekonomis yang dapat dirasakan langsung

Sejalan dengan beberapa faktor sebelumnya di atas yang menyebabkan memudarnya atau bahkan menghilangnya sistim begae besiru saat ini tidak lain karena adanya nilai ekonomis dan non ekonomis yang secara langsung dapat dirasakan.

Sudah jelas bahwa jika sistim besiru ini masih diterapkan, maka yang melakukannya tidak akan mendapat upah berupa uang yang memang lebih menjadikan masyarakat untuk mau bekerja. Di balasnya pekerjaan yang dilakukan tersebut dengan tenaga dirasakan tidak epektif, karena kebutuhan dan pekerjaan masyarakat saat ini yang begitu kompleks. Secara tidak langsung, inilah dapat menghilangkan sistem yang dahulunya memiliki nilai fungsional tersebut. Karenanya fungsional dan tidak fungsionalnya sistim sosial pada masyarakat dapat dilihat dari perubahan masyarakat itu sendiri, seperti halnya dengan apa yang terjadi pada masyarakat Sasak ini.

6. Bergantinya tenaga manusia dengan mesin pada beberapa hal

Perubahan budaya fisik masyarakat dunia yang sudah dimulai sejak 1500 sampai saat ini, telah banyak membuat perubahan pada nuansa kebudayaan masyarakat, tidak terkecuali pada masyarakat Sasak di pulau Lombok. Perkembangan industri yang menurut Alvin Toffler (Herimanto \& Winarno, 2011: 81), seorang futurolog dikatakan sebagai gelombang kedua dari perubahan peradaban masyarakat, telah banyak menjadikan berkurangnya peran tenaga manusia digantikan dengan tenaga mesin yang menghendaki keterlibatan manusia yang sangat sedikit.

Beberapa pekerjaan di sawah yang dahulunya secara keseluruhan memerlukan tenaga manusia yang banyak, dewasa ini beberapa diantaranya tidak berlaku lagi. 
Sebelum padi ditanam, baik dengan cara lowong/dowong atau nayuk/najuk dengan sistem penanaman gugurancah, biasanya sawah tersebut akan dibajak baik dengan menggunakan karbau atau sapi, kemudian setelahnya memerlukan tenaga manusia. Begitu juga dengan beberapa pekerjaan lainnya. Karena itu, secara tidak langsung perkembangan ini mendorong adanya sistem upah dan mengurangi sistim besiru yang sudah berakar pada masyarakat Sasak.

7. Perubahan Pandangan Masyarakat

Perubahan pandangan masyarakat Sasak sehingga sistim besiru yang sudah ada dewasa ini sudah tidak berlaku lagi merupakan bagian dari akumulasi beberapa faktor yang menyebabkan tidak berlakunya lagi sistim besiru yang sudah diuraikan sebelumnya.

Perubahan pandangan ekonomi, perubahan hubungan sosial kemasyarakatan yang mengarah pada individualisme, pengaruh media massa, perkembangan kebutuhan masyarakat, berkembanganya sistem upah dan lain sebagainya mempengaruhi perubahan yang ada. Perubahan pandangan masyarakat dewasa ini lebih dipengaruhi keuntungan yang instan dan apa yang mereka ingin dapatkan adalah uang untuk memenuhi kebutuhan yang begitu banyak dan membutuhkan waktu yang instan juga.

Berdasarkan beberapa hal di atas yang menyebabkan terjadinya perubahan dan memudarnya sistim besiru pada masyarakat Sasak secara umum. Secara teoretis dapat dijelaskan dengan beragam teori perubahan sosial, terutama sekali yang berkaitan dengan pola dan pembagian kerja pada masyarakat Sasak. Karena bagaimanapun perubahan yang terjadi seperti diuraikan di atas, faktor determinannya bermuara pada adanya perubahan dalam hal pembagian kerja tersebut. Dimana perubahan dalam pembagian kerja memiliki implikasi yang sangat besar bagi struktur masyarakat (Ritzer \& Goodman, 2011: 90).

Memudarnya sistim besiru pada masyarakat Sasak, meminjam teorinya Emile Durkheim tidak lepas dari adanya perubahan dalam solidaritas masyarakatnya yang oleh Durkheim dikonsepsikan sebagai solidaritas mekanis dan organis.

Masyarakat dengan solidaritas sosial mekanis dicirikan dengan masyarakat yang pembagian kerja dalam masyarkatnya masih rendah, norma-norma yang cendrung 
represif, dan masih adanya kesatuan sosial dalam masyarakat yang tinggi (Kinloch, 2009: 90). Ciri-ciri demikian tidak jauh berbeda dengan masyarakat sebelum tahun 1970-an ke belakang, dengan salah satu solidaritas sosialnya seperti adanya sistim besiru.

\section{KESIMPULAN}

Masyarakat Sasak di Lombok memiliki keragaman sistem sosial yang dapat meningkatkan integrasi sosial mereka. Sama seperti suku-bangsa lainnya, masyarakat Sasak yang secara umum secara ekonomi masih agrarais memiliki ciri tersendiri yang membedakannya dengan masyarakat suku-bangsa lainnya, dan tentunya sistem sosial yang berupa nilai-nilai dan norma tersebut merupakan local genius atau kearifan lokal yang dimiliki masyarakat Sasak.

Salah satu diantara sekian banyak kearifan lokal masyarakat Sasak dapat diidentifikasi dari banyaknya sistem integrasi sosial atau sistem solidaritas yang dimilikinya, baik itu yang terlembaga maupun yang muncul dan dapat diidentifiksi dari budaya simbol yang ada. Namun disadari bersama bahwa beberapa sistem persatuan masyarakat Sasak tersebut, dengan adanya perubahan kompleks dalam segala hal, menciptakan juga tatanan baru yang tentunya lebih sesuai dengan jiwa zamannya. Sehingga tidak sedikit dari sistem sosial pada masa lalu tersebut ikut berubah di dalamnya, atau bahkan hilang sama sekali.

Sebagai masyarakat agraris yang memiliki identitas tersendiri, baik secara kontekstual, tekstual, maupun yang tertera dalam budaya simbol, masyarakat Sasak identik dengan kerukunan dalam bingkai persatuan dan gotong-royong. Dalam hal kontekstual, adanya perkumpulan kelompok banjar, sistim besiru, gotong royong dalam pembuatan rumah, gotong royong dalam pembuatan bangunan-bangunan umum seperti madrasah, masjid dan lain sebagainya sudah merupakan kenyataan faktual tersendiri yang pernah dan masih ada pada masyarakat Sasak. Adapun dalam hal tekstual dan simbol persatuan yang ada bisa muncul dari kebiasaan-kebiasaan masyarakat yang mengarah pada adanya persatuan sosial, sistem duduk bersila (tokol besile), fungsi berugak, dan lain sebagainya. Semuanya mengandung dan memiliki nilai fungsional bagi integrasi masyarakat Sasak.

Terdapat perbedaan tersendiri mengapa beberapa diantara sistem persatuan sosial 
bisa luntur dan yang lainnya tetap bertahan. Jawabannya ada pada ada tidaknya keuntungan ekonomis yang didapatkan. Jika sistim besiru, dan sistem gotong royong pada saat pembuatan rumah imbalannya adalah tenaga juga, maka sebaliknya, ketika membentuk kelompok banjar, mereka akan mendapatkan barang yang diperlukan pada saat mereka memerlukannya yaitu ketika acara begawe yang memang memerlukan modal yang besar. Karena itu, nilai ekonomis yang terkandung di dalamnya merupakan pembeda, sehingga ada yang ditinggalkan dan ada juga yang tetap bertahan.

\section{DAFTAR PUSTAKA}

Andi Ima Kesuma. 2012. Moral Ekonomi Manusia Bugis. Makassar: Rayhan Intermedia.

Assifie, B. 2001. Etnografi dan Metode Observasi Partisipasi dalam Agus Salim (peny). Teori dan Paradigma Penelitian Sosial (pemikiran Norman K. Denzin \& Egon Guba, dan Penerapannya). Yogyakarta: Tiara Wacana.

Herimanto \& Winarno. 2011. Ilmu Sosial \& Budaya Dasar. Jakarta: Bumi Aksara.

Kinloch, Graham C. 2009. Perkembangan dan Paradigma Utama Teori Sosiologi. Bandung: Pustaka Setia.

Kuntowijoyo. 2005. Pengantar Ilmu Sejarah. Yogyakarta: Bentang.

Kuntowijoyo. 2008. Penjelasan Sejarah (Historycal Explanation). Yogyakarta: Tiara Wacana.

Kuswarno, E. 2009. Fenomenologi: Konsepsi, Pedoman, dan Contoh Penelitian. Bandung: Widya Padjajaran.

Lalu Murdi. 2013. Perubahan Perilaku Laki-laki terhadap Perempuan (Kasus Perempuan Sasak di Lombok Timur-NTB 1943-2012). Tidak Diterbitkan. Makassar: Program Pascasarjana Universitas Negeri Makassar (UNM).

Maryaeni. 2005. Metode Penelitian Kebudayaan. Jakarta: Bumi Aksara.

Nasikun. 2011. Sistem Sosial Indonesia. Jakarta: Rajawali Pers.

Ritzer G \& Goodman D. J. 2011. Teori Sosiologi: Dari Teori Sosiologi Klasik Sampai Perkembangan Mutakhir Teori Sosial Postmodern. Jakarta: Kreasi Wacana.

Setiadi, E.M \& Kolip U. 2011. Pengantar Sosiologi: Pemahaman Fakta dan Gejala Sosial. Jakarta: Kencana.

Soekanto, S. 1984. Teori Sosiologi tentang Perubahan Sosial. Jakarta Timur: Ghalia Indonesia.

Sri-Edi Swasono. 2014. Kebangsaan Kerakyatan dan Kebudayaan. Yogyakarta: UTSPress.

Sri-Edi Swasono. 2014. Krisis Kepemimpinan Rezim Merampok Negara. Yogyakarta: UTS-Press.

Sudirman \& Bahri. 2014. Studi Sejarah dan Budaya Lombok. Benyer-Lotim:

PUSAKANDA.

Tolomundu \& Yamin. 2008. Besiru: Revitalisasi Banjar di Lombok. Makassar: BaKTI/SoFEI.

Wineburg, Sam. 2006. Berpikir Historis: Memetakan Masa Depan, Mengajarkan Masa Lalu. Alih bahasa oleh Masri Maris. Jakarta: Yayasan Obor Indonesia. 